\title{
Do as I say, not as I do: drivers of sustainability reporting Spanish universities
}

\begin{abstract}
This paper attempts to find explanatory factors for the sustainability disclosure of public universities in Spain. It analyses the influence of some factors that previously been used in the private service sector but adapted to the particularities of higher education. It applies the index methodology to measure the information content of annual or sustainability reports. The total disclosure is divided into economic, environmental and social areas. In analyzing the features of the sustainable universities, the Spearman correlation coefficient is applied using the index scores. The variables included are: quality of teaching, performance in research, quality of the website, revenue per student, number of full-time equivalent students, and age of the university. The results show significant differences in the quantity of information disclosed by Spanish universities. Research performance is identified as the best explanatory factor for the disclosure of universities. These results are consistent with the principles of legitimacy theory and, at the same time, suggest that outstanding research institutions are more sensitive to social demand for proper accountability.
\end{abstract}

Keywords: university social responsibility, accountability, sustainability performance indicators, legitimacy theory.
Volume 2 Issue 5 - 2018

Emilio Martín, Jose M Moneva

Department of Economía, Universidad de Zaragoza, Spain

Correspondence: Emilio Martín, Universidad de Zaragoza, Facultad de Economía y Empresa, Gran Vía, Tel +34 876844642 , Fax+34976761 769, Email emartin@unizar.es

Received:September 10, 2018 | Published: October 04, 2018

\section{Introduction}

In the last decade, there has been increasing interest in incorporating sustainability and social responsibility issues into the sphere of higher education. Higher education institutions have a dual responsibility in the promotion of sustainability since, like any other institution, their activity has economic, environmental and social consequences but, furthermore, they act as a role model for society, influencing the behaviour of future leaders. ${ }^{1-3}$ The contribution of the universities to sustainability is mainly being carried out by means of different declarations with which they try to show their commitment to this issue. ${ }^{4}$ Nowadays, there are more than 30 Sustainability in Higher Education declarations and more than 1,400 universities have signed at least one of them. ${ }^{5}$ However, most of these declarations have been criticized for not stipulating measures to ensure comparability and for their lack of compulsory requirements to demonstrate accountability. We are used to talking about sustainable campuses and different desirable practices aimed at promoting social responsibility in training and research but, generally, these practices are not part of any global strategy of the institution and, frequently, there are no instruments to measure their results and to hold them accountable to stakeholders. ${ }^{6}$

Beyond initiatives aimed at improving the environmental performance of universities in their three core functions (teaching, research and campus life), the social responsibility of higher education institutions also requires the establishment of mechanisms to measure and communicate the results of the execution of the strategy to the different stakeholders. ${ }^{7}$ Transparency is a basic principle of corporate social responsibility ${ }^{8}$ and implies the duty of reporting about all the proceedings of the entity, taking into account the relationships and the information needs of the different stakeholders. However, traditionally, the accountability of public entities has been focused on the information disclosed in the financial statements without paying attention to other stakeholders' interests. Thus, universities should complement financial reporting with other performance indicators, particularly at a moment of financial constraints which make it more important than ever to justify the proper use of the public resources they have received. The internet provides a potential disclosure mechanism with many advantages for communicating with the stakeholders because it disseminates the information easily and quickly. ${ }^{9}$

Although sustainability reporting in universities is still in its early stages ${ }^{10}$ an increasing number of universities are completing their annual reports with figures about their academic activity or even publishing some type of sustainability report following a triple bottom line approach. ${ }^{11,12}$ The motives that drive universities to voluntarily reveal this type of information are not clear, but they may be influenced by institutional or reputational factors. There is a doubt as to whether sustainability reporting obeys social responsibility criteria or whether it is just an opportunistic practice of universities to strengthen their competitiveness.

This paper analyses, from a triple-bottom line approach, the information in annual reports ${ }^{1}$ disclosed online by Spanish universities for the year 2010 in order to evaluate the development of the accountability culture. The analysis includes the compulsory disclosure of financial information aimed at assuring that the resources have been managed according to law and other disclosures focused on social and environmental issues. The purpose is to evaluate to what extent the reporting practices of Spanish public universities are aligned with social responsibility principles. Furthermore, it will look into the impact of some institutional characteristics on the level of disclosure. In particular, it will examine the role of variables like the size, the age, the quality of the webpage, the level of incomes and the reputation of the institution in teaching and research. The paper aims to contribute to the scarce literature on university social responsibility and, in particular, on sustainability reporting. ${ }^{13,14}$ Most prior studies are

${ }^{1}$ The annual reports analysed include financial statements, the academic report and the sustainability report, if available. 
case studies that focus only on one dimension of sustainability and, unlike for the private sector, there is a lack of studies analyzing the explanatory factors of sustainability reporting. The remainder of the paper is organized as follows. The next section discusses the current state of sustainability reporting in universities and its determinants. Section 3 describes the methodology applied, especially the disclosure index. Finally, Sections 4 and 5 present the findings and conclusions, respectively.

\section{Background}

\section{Sustainability reporting in higher education}

Sustainability reports have a double role ${ }^{15,16}$ Firstly, to assist in understanding and managing the effects of sustainability developments on the organization's activities and strategy and, secondly, to communicate the institution's efforts and sustainability progress to its stakeholders. Thus, sustainability reporting constitutes an important tool of corporate social responsibility (CSR) since communication plays a key role in the understanding, harmonization and alignment of the interests and goals of organizations and stakeholders. Although there are several mechanisms proposed for sustainability reporting, the Global Reporting Inititative (GRI) guidelines ${ }^{17}$ are the most extended. The GRI Guidelines offer reporting principles, standard disclosures and an implementation manual for the preparation of sustainability reports by organizations, regardless of their size, sector or location. ${ }^{16,18}$ In the case of universities, an increasing number of institutions are applying the GRI guidelines (Table 1). The number of GRI-referenced sustainability reports in the university sector has increased from 2 in 2006 to 22 in 2012. Furthermore, 6 of the 22 sustainability reports of 2012 have been published by Spanish universities, which reflects the engagement of the Spanish higher education system with this phenomenon. Social responsibility and accountability constitute one of the pillars of the Strategy University $2015 .^{2}$

The lack of specific guidelines for universities could be the main reason for the later and lower level of development in comparison with other sectors. The current GRI guidelines need to be adapted and completed to include the core competences of universities, teaching and research. ${ }^{15}$ As a consequence, there have been several proposals of guidelines developed ad hoc for universities which incorporate educational dimensions into the sustainability reports. Among them, Lozano $^{15}$ indicates the National Wildlife Federation's State of the Campus Environment, the Sustainability Assessment Questionnaire, Higher Education 21's Sustainability Indicators and the Auditing Instrument for Sustainability. Apart from them, in 2003, the University Leaders for a Sustainable Future presented a draft with a standardized version of the GRI guidelines for universities that included 13 educational indicators. In the Spanish context, the Catalogue of indicators for the Spanish Higher Education System, issued by the Council of Universities and the project Responsible Universities, led by the University of Zaragoza, constitute the most relevant initiatives in this matter. In particular, the battery of indicators proposed in the project Responsible Universities has been taken as a reference by most of the 14 Spanish universities issuing Sustainability Reports. ${ }^{3}$

${ }^{2}$ The Strategy University 2015 is a Spanish Government initiative that establishes the framework for modernizing the Spanish University System in the context of the European Higher Education Area.

${ }^{3}$ Although there are 14 Spanish universities that elaborate sustainability reports following the GRI recommendations, only six appear in the sustainability disclosure database. ${ }^{22}$
Table I Universities publishing GRI referenced sustainability reports

\begin{tabular}{lll}
\hline Period & Total Reports & Spanish \\
\hline 2006 & 2 & 1 \\
2008 & 10 & 2 \\
2010 & 12 & 4 \\
2012 & 22 & 6
\end{tabular}

Source Based on GRI sustainability disclosure database

The lack of generally accepted sustainability reporting guidelines and the diffuseness of the concept of university social responsibility may also explain the relatively scarce number of studies dealing with this issue. Some of the most representative contributions are case studies analyzing the initial stages of the process of implementation of a sustainability report in a specific context. Larrán ${ }^{15,19}$ carry out some studies focused on Andalusian universities). There are also examples of comparative analyses of the information disclosure and sustainability practices adopted by universities in Sweden ${ }^{20}$ and the US $^{17,21}$ but they are mainly focused on the environmental dimension. Based on the GRI guidelines, Lozano ${ }^{15}$ develops a specific tool, the GASU (Graphical Assessment of Sustainability in Universities) to facilitate the analysis and comparison of universities' sustainability reports. It is applied to assess the disclosures of 12 international universities that had published sustainability reports following the GRI guidelines although they did not refer to the same period. ${ }^{10}$ Fonseca ${ }^{11}$ also create their own method, taking the GRI guidelines and the Campus Sustainability framework as their references, to analyze sustainability reporting in Canadian universities. In Spain, Moneva and Martin apply a disclosure index to evaluate to what extent the annual reports published by a group of 9 public universities contain triple bottom line disclosures. Whatever the sample, the scope or the methodology applied, these studies share similar conclusions: sustainability reporting in the higher education sector is still in its early stages and there is a wide divergence of practices between universities.

\section{Determinants of sustainability reporting}

The search for relationships between corporate characteristics and the extent and quality of the information disclosed by firms has been one of the major concerns of social and environmental accounting research. ${ }^{23,24}$ Since the 80 s, a number of studies have looked for a pattern of behaviour that enables us to understand and to predict the social responsibility disclosure of private sector organizations. Size and profitability are the factors most frequently studied as determinants of the level of disclosure, although other variables, such as age, industry category and stakeholder power have also been evaluated. ${ }^{25,26}$ The stakeholder and legitimacy theories are usually used to underpin the theoretical framework of these studies. Stakeholder theory assumes that organizations should be managed in the interest of all their constituents, not only in the interest of shareholders. It implies responding to a number of, sometimes conflicting; external demands. ${ }^{27}$ Legitimacy theory holds that organisations seek to establish congruence between the social values associated with their activities and the norms of acceptable behaviour in the larger social system of which they are a part. When an actual or potential disparity exists between the two value systems, a threat to organisational legitimacy will arise. ${ }^{28,29}$ Under legitimacy theory, sustainability reporting may be viewed as a part of a corporation's 
overall strategy to build and maintain its legitimacy. ${ }^{24,30,31}$ aimed at reducing the gap between the expectations and perceptions of relevant stakeholders of the firm. Competitive sectors stimulate organizations to implement and disseminate corporate social responsible practices and the information revealed may be strongly biased towards the interests of the firms. ${ }^{32}$ In many ways, the theories are complementary rather than opposites. ${ }^{33}$ In relation to the size of the organization, the most supported hypothesis is that larger organizations should be more prone to disclose sustainability information than smaller ones, because they are subject to stronger pressure from stakeholders and, consequently, they are more closely scrutinized. Furthermore, they can usually afford the human and financial resources required for these purposes. Some studies coherent with this relationship are those of Cowen ${ }^{25}$, Gray ${ }^{26}$,Garcia-Ayuso ${ }^{23}$ and Artiach $^{34}$.

In the same way, the literature seems to indicate that the profitability of the organization is another factor positively related to the extent and quality of corporate social disclosure. ${ }^{26,35}$ Nevertheless, there are studies, such as that of Llena ${ }^{36}$ which do not find any significant relationship. Furthermore, even assuming this relationship, its direction of causality is not clear. Recent studies carried out in Germany and Spain suggest that financial performance precedes social performance. Thus, firms with higher financial performance may use their surplus for further improvements of their social performance. ${ }^{37,38}$

There are few studies analysing the determinants of social responsibility disclosure in public sector organizations ${ }^{13}$ although Lamprinidi ${ }^{39}$ state that the reasons for disclosure should not differ from those of private companies. García-Sánchez $z^{40}$ observes positive associations between the transparency level and the economic status and size of Spanish municipalities. However, Farnetti, ${ }^{41}$ in a study focused on the Australian public sector agencies, suggest that the leadership of some individuals within the organizations is the main reason to start sustainability reporting in the public sector sphere. Levy ${ }^{42}$ highlight the knowledge of issues and procedures as well as the existence of social and material incentives as the factors influencing public organizations to develop pro-environmental behaviours. At higher education level, Gallego ${ }^{9}$ identify the complexity, internationality and profitability of the institution as the significant factors explaining the online disclosure of information by Spanish universities, which connects with both the legitimacy and stakeholder theories. This paper tries to find explanatory factors for the sustainability disclosure of public universities. To do so, we will analyse the influence of the most relevant factors that have been previously tested in the private sector, adapting them to the particularities of higher education.

\section{Methodology}

The study covers all the public universities in Spain, including two distance learning universities. The full list of the institutions and their URLs can be found in the Appendix. The Spanish higher education system is made up of 72 universities located throughout Spain, 50 of which have public status while the Catholic Church and other private institutions run the others. They enrolled 1,582,714 students in the 2011/12 academic year. Although defined as self-governing bodies, Spanish universities are highly dependent on public funds, which represent around $78 \%$ of their resources, whereas tuition fees account for about $18 \%$ of the university budget. ${ }^{43}$ Therefore, these institutions must be accountable to citizens with respect to the use of the money they have contributed. This kind of accountability includes not only providing information aimed at ensuring that public money has been spent legally but also other input and output measures useful in terms of evaluating the activity carried out. The methodology applied to measure the information content of annual reports published online by universities is based on the elaboration of disclosure indexes. A disclosure index is a qualitative-based instrument designed to measure a series of items which, when aggregated, give a surrogate score indicative of the level of disclosure in the specific context for which the index was devised. ${ }^{44}$ Basically, the elaboration of a disclosure index is carried out in two steps:

\section{To select the items to be included in the scoring sheet}

\section{To establish the weighting of each item}

Several studies apply the index methodology to measure the information content of annual or sustainability reports issued by both public and private organisations. ${ }^{12,45}$ As we can see in Table 2, they can be classified according to whether the items are weighted or not and to whether they are evaluated dichotomously or according to the quality of individual disclosures. For the purpose of this paper, an unweighted and dichotomous index is created, similar to that defined by Cooke ${ }^{46}$ in which it is assumed that each item of disclosure is equally important. Although each class of user would attach different weights to the items, the research aim is not focused on any particular user group. The index will calculate the ratio of actual scores awarded to an organization -in our study, Spanish public higher education institutions- to the scores which that organization was expected to earn. Consequently, an entity is not penalised for those items that are not relevant to it. The ratio $(\mathrm{TD} / \mathrm{M})$ achieved by entities varies between 0 and

The mathematical expression of the index is as follows:

$$
T D=\sum_{i=1}^{m} d_{i}
$$

Where $\mathrm{d}, 1$ if the item di is disclosed and 0 if not; $\mathrm{m} \leq \mathrm{n}$

$$
M=\sum_{i=1}^{n} d_{i}
$$

Where $\mathrm{d}$, expected item of disclosure; $\mathrm{n}$, the number of items which the entity is expected to disclose.

Thus, the total index (TI) for each entity becomes TD/M (number of disclosures/ number of items applicable).

\begin{tabular}{|c|c|c|}
\hline & Unweighted & Weighted \\
\hline & Cooke $e^{46}$ & Singhvi \& Desai [197I] \\
\hline & Dixon Coy \& Tower ${ }^{44}$ & Chow \& Wong-Boren ${ }^{46}$ \\
\hline \multirow[t]{5}{*}{ Dichotomous } & Gallego et al ${ }^{9}$ & Wallace [1988] \\
\hline & Moneva \& Martin 12 & \\
\hline & Lozano $^{10}$ & \\
\hline & Wiseman [1982] & Buzby 48 \\
\hline & Giroux [1989] & Robbins \& Austin [1986] \\
\hline \multirow[t]{3}{*}{ Qualitative } & & Coy ${ }^{44}$ \\
\hline & & Nelson [1997] \\
\hline & & Banks ${ }^{49}$ \\
\hline
\end{tabular}

Table 2 Index Construction Methods used by different researchers

Source Author's elaboration from the classification of Coy, ${ }^{44}$ 
The index is made up of the set of performance indicators recommended in the Project "Responsible Universities" for the elaboration of sustainability reports by universities (Appendix). This battery of indicators is structured on the basis of triple bottom line reporting and it takes into account the indicators suggested in prior initiatives such as the EUROSTAT indicator system, the set of performance indicators for the Spanish Higher Education System, the Higher Education 21st Sustainability Indicators and the College Sustainability Report Card. In total, there are 30 items embracing indicators within the economic (10), social (14) and environmental (6) categories. Because sustainability reporting is a voluntary activity, the universities may disseminate this information using different types of reports. As a result the information has been collected from financial statements, annual course reports and, where appropriate, the sustainability reports published online by each university for the year 2010. In order to analyse the features of the most sustainable universities (at least from the point of view of transparency) the Spearman correlation coefficient is applied using the score of the indexes and different indicators representative of the variables that, in accordance with the previous section, the literature has identified as determinants of sustainable disclosure in for-profit organizations. The Spearman coefficient is a less restrictive variation of the Pearson coefficient because it does not require normality. It reflects the degree of linear relationship between two variables and ranges from +1 to -1 . A correlation of +1 implies a perfect positive linear relationship between the variables.

To evaluate the effect of size, we use the number of the full-time equivalent students of the university. The more students, the higher the number of relationships within the organization and the number of stakeholders to be accountable to and, thus, in accordance with the initial hypothesis, the higher the disclosure expectations.

The age of the university acts as an indicator representative of the reputation of the institution. It is expected that established universities will disclose more information than new universities. Furthermore, in the Spanish higher education system, the oldest universities tend to be multidisciplinary institutions offering a wider range of studies than the more recent specialized institutions, which increases the complexity of their relationships with stakeholders.

The profitability of a public university is a term that can be analysed from different angles. On the one hand, from an economic perspective, although the public universities do not pursue surpluses, it is expected that universities with higher incomes will tend to reveal more information to satisfy their stakeholders' needs. Furthermore, they need to be more accountable to society since most of the resources come from public money. On the other hand, from an interpretation of profitability as a proxy for the success of the organization, in the case of a university, it should be measured by its reputation in teaching and research. Therefore, the better the performance, the more information the institution is expected to disclose in order to justify their public funding and to reduce the risk of being viewed negatively by public opinion. The variables included in the analysis to test their influence on the sustainability disclosure of universities are the following:

Quality of teaching: is used as a proxy for the results of the quality education index of the Spanish universities of Buesa. ${ }^{47}$ This index measures the quality of education through 18 educational variables that have been more frequently used by international rankings. A factorial analysis is applied to synthesize these variables into 5 sub- indexes (factors) related to:

a. The relative size of the university

b. Human resources

c. Infrastructures and computer resources

d. Academic performance of students and library facilities

e. PhD assessment

The results of the ranking are normalized, so that the best university scores 100 , while the others score in relation to it.

Performance in research: the results of the Ranking 2010 in the research productivity of Spanish public universities elaborated by Buela $^{48}$ are used to test the hypothesis that outstanding research universities are also more accountable and socially responsible. This ranking is carried out annually to measure the research performance of Spanish universities taking into account the following factors:

a. JOURNAL ARTICLES INDEXED IN THE JCR (JOURNAL CITATION REPORT) (18\%)

b. SIX-YEAR RESEARCH PERIODS (\% of senior professors awarded two or more research periods and lecturers with one or more) $(16 \%)$

c. RESEARCH + DEVELOPMENT PROJECTS (16\%)

d. DOCTORAL DISSERTATIONS (14\%)

e. GRANTS FOR TRAINING UNIVERSITY TEACHERS (12.5\%)

f. DOCTORAL PROGRAMS AWARDED A QUALITY MENTION (12.5\%)

\section{g. PATENTS (11\%)}

The weighting of the different factors composing the index (in brackets) was assigned according to the opinion of academics participating in a previous survey carried out by Buela ${ }^{48}$ for this purpose. The highest assessed university receives a score of 100 and the rest are assessed in comparison to it.

Quality of the website: since the analysis is focused on the information disclosed online, the differences between universities may be due to the visibility and activity of their webpages. So, in the case of a significant correlation, the results would not be showing a stronger commitment to sustainability disclosure in universities with higher levels of disclosure but are just the consequence of having a more developed communication channel. In order to evaluate this possible influence, the position of each university in the world ranking web of universities (Webometrics), elaborated every six months by the Cybermetrics Lab, ${ }^{8}$ is introduced into the study. The ranking is performed to provide reliable, multidimensional, updated and useful information about the performance of more than 12,000 universities from all over the world based on their web presence and impact. The factors included in the composite indicators are:

Presence (P).[20\%]: The total number of webpages hosted in the main web domain (including all the sub domains and directories) of the university as indexed by the largest commercial search engine.

Visibility (V)[50\%]: The quality of the contents is evaluated through a "virtual referendum", counting all the external in links that the University web domain receives from third parties. 
Openness (R)[15\%]: The global effort to set up institutional research repositories is explicitly recognized in this indicator that takes into account the number of rich text format files (pdf, doc, docx, ppt) published in dedicated websites according to the academic search engine Google Scholar.

Scholar Excellence (Sc).[15\%]: Number of academic papers supplied by Scholar Google and Scimago that are among the 10\% most cited papers in their respective scientific fields.

The scores of the variable are transformed using the e- $\ln (\mathrm{x})$ to facilitate the interpretation of the results of the correlation analysis, so positive values mean that the quality of the web and the sustainability disclosure are positively related.

Revenues per student: this variable is used as a proxy for the financial richness of the universities and, as a consequence, of their capacity to devote resources to sustainability issues. Furthermore, because the incomes mainly come from public sources, it is expected that universities with more resources will strengthen their accountability to society.

Number of full-time equivalent students (FTES): this variable is used as a proxy for the size of the institution whether larger institutions are more willing to report sustainability information than smaller ones. This information has been collected from the statistics of the Spanish University System issued by the Department of Education for academic year 2009/10

Age of the university: this variable is used to test the hypothesis that, in accordance with most prior studies. ${ }^{49,50}$ older universities disclose more information than younger ones because they tend to have a stronger reputation. The variable is calculated as the difference between 2010 and the foundation year of the institution (Table 3).

Table 3 Descriptive statistics

\begin{tabular}{|c|c|c|c|c|c|}
\hline & Mean & Min & Max & Median & SD \\
\hline Students (Ftes) & 26,192 & 5,611 & 145,938 & 22,147 & 22,723 \\
\hline Age (Years) & 125 & 15 & 794 & 33 & 208 \\
\hline $\begin{array}{l}\text { Revenues/Student } \\
(€)\end{array}$ & 7,190 & 1,189 & 15,946 & 7,070 & 2,400 \\
\hline Webometrics & 629 & 41 & 2,942 & 525 & 490 \\
\hline $\begin{array}{l}\text { Quality Of } \\
\text { Teaching (\%) }\end{array}$ & 64.05 & 28.9 & 100 & 60.6 & 15.04 \\
\hline $\begin{array}{l}\text { Research } \\
\text { Performance (\%) }\end{array}$ & 52.45 & 31.69 & 100 & 50.1 & 14.49 \\
\hline
\end{tabular}

\section{Results}

Table 4 shows the level of sustainability disclosure in the annual reports published in the webpages of the Spanish universities, both the results of the index and the partial results in each of its three key areas of accountability (economic, social and environmental). In general, it is evident that the information in the annual reports published online by Spanish universities does not fulfil sustainability reporting principles since, on average; they only disclose $59 \%$ of the performance indicators included in the index. Furthermore, there is great heterogeneity in the behaviour of universities, especially in the environmental and social dimensions. There are institutions with high levels of disclosure (the University of Cordoba scores 94\%) whereas others do not reach $30 \%$. The individual analysis of each of the three areas of information that make up the index reveals the following results (Table 5):

Table 4 Sustainability disclosure by Spanish universities (\%)

\begin{tabular}{llllll}
\hline & Mean & Min & Max & Median & SD \\
\hline Total Disclosure & 59 & 29 & 94 & 55 & 20.16 \\
$\begin{array}{l}\text { Economic } \\
\text { Disclosure }\end{array}$ & 75 & 40 & 90 & 80 & 20.32 \\
$\begin{array}{l}\text { Environmental } \\
\text { Disclosure }\end{array}$ & 27 & 0 & 100 & 0 & 37.14 \\
$\begin{array}{l}\text { Social Disclosure } \\
\text { E }\end{array}$ & 36 & 100 & 64 & 20.63 \\
\hline
\end{tabular}

Economic dimension: most of the universities show a similar level of disclosure, revealing the majority of the required performance indicators. Most of this information is compulsory in the Budget that the universities are required to report every year together with the rest of the financial statements (Statement of financial position, Statement of financial performance, Statement of changes in net assets/equity, Cash flow statement and Notes). The Budget has traditionally been, according to Martín, ${ }^{51}$ the central element in the accountability of Spanish universities, more focused on the stewardship of public money than on performance measurement and management control. Only a few performance indicators relating to very specific issues, such as the accomplishment of the terms of agreements with suppliers and procurement practices or the percentage of the budget assigned to quality programs, are not usually disclosed by Spanish universities.

Environmental dimension: the universities show the lowest level of disclosure, without revealing any indicator in most cases. Only the University of Huelva includes the 7 items suggested, scoring $100 \%$ of disclosure in this area. This general lack of information contrasts with the multiple initiatives undertaken by the universities concerning the environmental management of their campuses. The report of Barañano ${ }^{22}$ about the state of social responsibility at Spanish universities indicates that $70 \%$ of Spanish universities consider the environmental area as the dimension of sustainability in which they are making the biggest progress. In particular, they highlight their efforts in waste management, recycling and energy-saving practices. For this purpose, most of the universities have created the so-called "Green Offices" or other similar units in charge of coordinating the environmental practices carried out by the institutions and to communicate with the university community. Therefore, most of the environmental indicators suggested are available within the institutions but they refuse to disclose this information in their annual reports. This lack of data measuring and quantifying the results of these practices may suggest that environmental performance is not a priority on the agenda of universities or, at least, all the members of the governance board are not sufficiently involved. This is coherent with the results of the research project conducted by Larrán ${ }^{19}$ which analyses the sustainability policies of Spanish universities. ${ }^{4}$

\footnotetext{
4 "Analysis of the level of development of social responsibility policies in the Spanish universities". ${ }^{19}$
} 
Table 5 Spearman correlation results

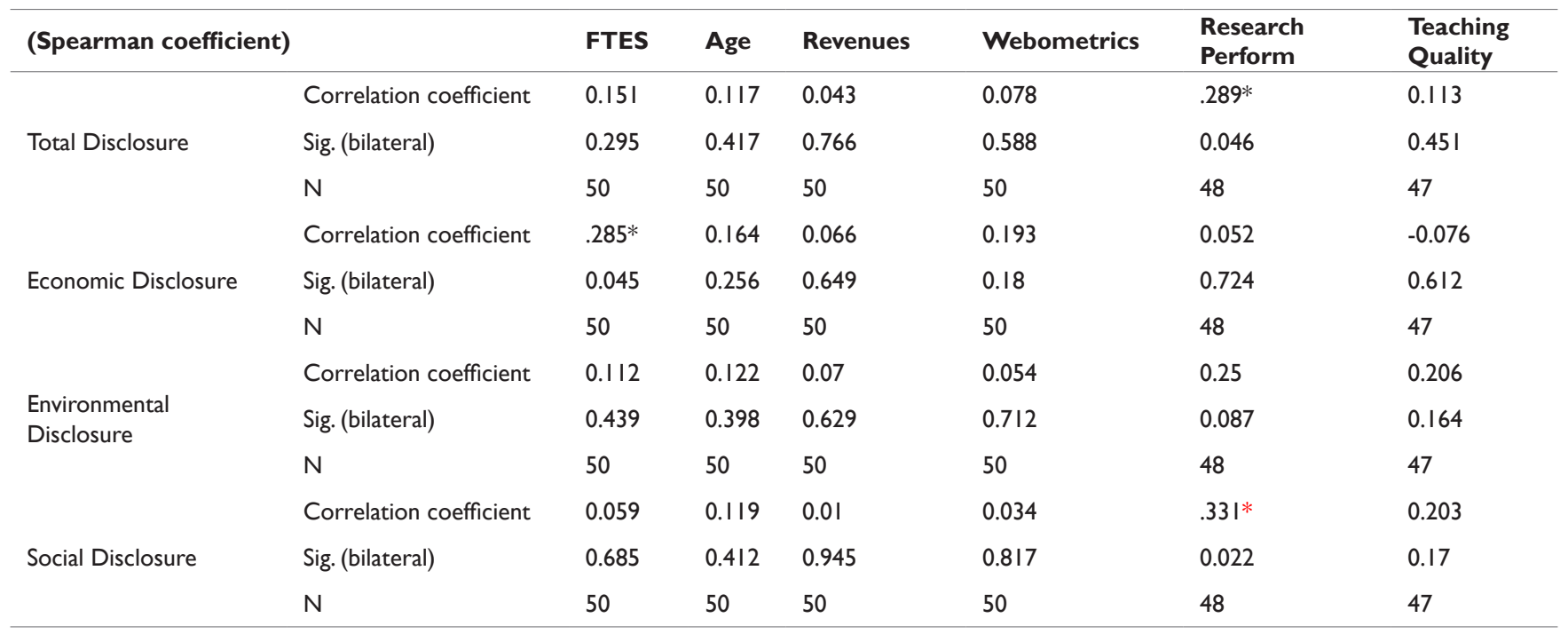

Social dimension: the level of disclosure achieved is, on average, $63 \%$. This is high in comparison with the environmental dimension but less than that found in the economic dimension. On the one hand, universities tend to satisfy the information needs of their stakeholders with respect to teaching and research, providing ample information about the available resources, the studies and the courses offered as well as about the campus facilities, but they are reluctant to report about their outputs and quality measures. For example, few universities report the results about research assessments or teaching performance through academic failure/success rates and the employability of graduates. On the other hand, the disclosures about social policies and cooperation programs carried out by the universities are quite erratic. In general, the information provided on this matter is qualitative without measuring the results of the activities. Something similar occurs with personnel, where the best practices of universities are focused on training programs and gender equality. The reluctance of the universities to report absenteeism rates and other conflicts related to the working environment could be due to the high level of sensitivity and confidentiality of this information even when it is disclosed in aggregate form. Table 5 shows the results of the analysis of correlations among the scores of the disclosure index and the six academic and institutional variables described before as potential determinants of social responsibility disclosure. Although the relationships are positive for all the explanatory factors considered, only performance in research shows a statistically significant value. The size of the institution, measured by means of the FTES, is the best explanatory factor for the online disclosure of economic information by the universities. Large universities usually have more developed managerial structures with specific units in charge of collecting financial information, calculating the cost of the services and carrying out internal audits. These universities also usually have more sophisticated webpages ${ }^{5}$ and, as a consequence, the variable webometrics also seems to have a positive influence

${ }^{5}$ The analysis of correlations identified a highly significant positive relationship between FTES and webometrics, although this information does not appear in the paper on the disclosure of economic information, although the correlation is not statistically significant. In the environmental and social areas, performance in research and quality of teaching are the best explanatory factors for the level of disclosure of the universities while the other factors seem to have little influence. Thus, the results suggest that the variables related to academic reputation, especially research performance, are the most determinant factors of sustainability reporting in Spanish universities. The positive relationship between performance in teaching and research and the scope and depth of their public accountability, particularly the social dimension of the information index, shows the interest of these institutions in being legitimated by society. Universities with a better performance may use sustainability reporting to improve their reputation and as an instrument of competitive differentiation.

\section{Conclusion}

This paper has carried out an analysis of the annual reports published online by Spanish public universities to measure the scope and usefulness of the information disclosed from a triple bottom line perspective. The main findings and reflections arising from the results of the study are the following. It is evident that the annual reporting of Spanish universities does not satisfy the triple bottom line requirements for accountability. In most cases, there is no balance among the different areas of sustainability and the information does not provide a global view of the performance of institution. The accountability of universities basically involves the economic dimension, revealing the information required to ensure the financial control of the entities. This is coherent with the results of prior studies which emphasized that the annual reporting of public universities was biased towards budgetary issues to the detriment of other noneconomic performance matters. ${ }^{12,52,53}$ The financial indicators are usually supplemented with information about the academic activity of the institutions, whereas environmental indicators are rarely disclosed in annual reports, even though the universities participate in many activities to raise public awareness about environmental concerns. 
Almost all universities have created specific units or departments (generally named "Green office") in charge of coordinating the different campaigns carried out by the institution and have signed different declarations for sustainability, but they fail to measure and communicate the results. Similar to what Larrán and López ${ }^{14}$ found for Andalusian universities, Spanish universities, as a whole, do more than they report in the field of sustainability. The elaboration of a battery of indicators for higher education that included the social and environmental dimensions would provide a generally accepted framework to facilitate the disclosure and comparability of the most relevant information in all the areas of performance. However, the advantages of regulating the information contained in annual reports, such as standardization and homogenization, would contrast with the voluntary nature of the disclosures, one of the pillars of CSR. The results suggest that academic performance, in particular research, is the most relevant factor to explain the sustainability disclosure of Spanish universities. This relationship supports the postulates of the legitimacy theory arguing that the main purpose of organizations when they disclose information is not to be accountable but to persuade stakeholders to trust in the organization and, as a consequence, annual reports usually emphasize the most favourable face of the entity. The benefits of increasing transparency and reporting the positive aspects of institutions are stronger when they operate in competitive environments. ${ }^{32,54}$ Although, traditionally, there has not been much competition in the Spanish university system, the development of the European Higher Education Area, which promotes student mobility, and the financial distress suffered by the Spanish public administration and the universities, particularly as a consequence of the current economic crisis, are shaping a new scene of competition among institutions to attract more students and private funds and to justify their use of public money. This new scenario might encourage some universities to look for competitive advantages by reporting their sustainability practices, a feature which will be gradually adopted by others through a process of imitation. ${ }^{55}$ Nevertheless, in the higher education environment, the fact that research quality was the best determinant factor for accountability may also suggest that universities outstanding in research are more innovative and sensitive to social demands. In this case, the elaboration of sustainability reports would represent a form of innovation in management to enable organizations to satisfy the information needs of stakeholders in a balanced way and to monitor the accomplishment of the long-term strategic goals of the institution.

This study is pioneer in the analysis of the determinants of sustainability disclosure in higher education institutions from a triple bottom line perspective. The lack of consensus on the most suitable indicators of sustainability in the higher education sphere also makes it difficult to carry out empirical analyses evaluating the accountability of higher education institutions from a triple bottom line perspective. It would be interesting to create a generally accepted battery of indicators to facilitate the elaboration and comparison of university sustainability reports. In Spain, the creation of a University Social Responsibility Committee by the Department of Education seems to be aimed at defining a comprehensive system of indicators that include the economic, social and environmental dimensions of the performance of universities. At international level, the development of a specific supplement for the higher education sector from the GRI would encourage the use and usefulness of the GRI guidelines in universities. ${ }^{56-59}$ Further research should be addressed to compare the sustainability reports published by universities worldwide in order to establish the common features of sustainability reporting in higher education and to analyse the influence of the factors tested in this study on disclosure. It would also be interesting to study the influence of other factors on disclosure, such as leadership and the participation of the institution in sustainability projects, which according to Arvidsson ${ }^{20}$ and Farnetti ${ }^{60}$ are relevant for developing a culture of accountability in the public sector.

\section{Acknowledgements}

None.

\section{Conflict of interest}

The author declares that there is no conflict of interest.

\section{References}

1. Guni. International Barcelona Conference on Higher Education: The social commitment of universities. UK: Declaration of Barcelona; 2004 $21 \mathrm{p}$.

2. Muijen H. Corporate Social Responsibility Starts at University. Journal of Business Ethics.2004;53(1-2):235-246.

3. Vallaeys F. Marco teórico de Responsabilidad Social Universitaria. Lima (Perú): Pontificia Universidad Católica del Perú; 2006.166 p.

4. Larrán M, López A. Son las Universidades Públicas Andaluzas Socialmente Responsables? Por qué?. Memorial Raymond Konopka. (Cádiz); España: hall Press Publishers; 2009. 29 p.

5. Grinsted T. Sustainable universities-From declarations on sustainability in higher education to national law. Environmental Economics. 2011;2(2):29-36.

6. Holdsworth S, Wyborn C, Bekessy S, et al. Professional Development for education for sustainability. How advanced are Australian universities? International Journal of Sustainability in Higher Education. 2008;9(2):131-146.

7. Gray R, Owen D, Adams C. Accounting \& Accountability: Changes and challenges in corporate social and environmental reporting. London: Prentice Hall; 1996. 332 p.

8. Spanish Association of Accounting and Business Administration. Marco Conceptual de la Responsabilidad Social Corporativa. Madrid: AECA; 2004. 7 p.

9. Gallego Álvaréz I, Rodríguez Dominguez L, García Sánchez I. Information disclosed online by Spanish universities: content and explanatory factors. Online Information Review. 2011;35(3):360-385.

10. Lozano R. The state of sustainability reporting in universities. International Journal of Sustainability in Higher Education. 2011;12(1):67-78.

11. Fonseca A, Macdonald A, Dandy E, et al. The state of sustainability reporting at Canadian universities. International Journal of Sustainability in Higher Education. 2010;12(1):22-40.

12. Moneva JM, Martín E. Universidad y desarrollo sostenible: análisis de la rendición de cuentas de las universidades desde un enfoque de responsabilidad social. Revista iberoamericana de contabilidad de gestión. 2012;10(19):18.

13. Ball A, Grubnic S. Sustainability accounting and accountability in the public sector. Unerman J, Bebbington J, O’Dwyer, editors. Sustainability accounting and accountability. UK: Routledge; 2007.300 p. 
14. Larrán M, Lopez A. Una propuesta de memoria de sostenibilidad universitaria como vía de diálogo con los diferentes grupos de interés. In: Cuesta M, De La Cruz C, Rodríguez JM. Responsabilidad social universitaria. La Coruña: Impreso en España; 2010:99-122.

15. Lozano R. A tool for a graphical assessment of sustainability in universities (GASU). Journal of cleaner production. 2006;14(9-11):963-972.

16. GRI. G4 Sustainaibility reporting guidelines: reporting principles and standard disclosures. Amsterdam (The Netherlands): Global Reporting Initiative; 2003. 97 p.

17. Shriberg M. Institutional assessment tools for sustainability in higher education". International Journal of Sustainability in Higher Education. 2002;3(3):254-270.

18. GRI. G3 Sustainaibility reporting guidelines. Amsterdam (The Netherlands): Global Reporting Initiative; 2006.170 p.

19. Larrán M, López A, Andrades FJ. Barreras y aceleradores para la implantación de la responsabilidad social en las universidades públicas españolas. Coimbra: Portugal: Comunicación presentada al XIV Congreso de AECA; 2010. 36 p.

20. Arvidsson K. Environmental management at Swedish universities. International Journal of Sustainability in Higher Education.2004;5(1):91-99.

21. Graedel TE. Quantitative sustainability in a college or university setting. International Journal of Sustainability in Higher Education. 2002;3(4):346-358.

22. Barañano M. La responsabilidad social como misión en las universidades españolas y su contribución al desarrollo sostenible. Informe del proyecto de investigación (EA2011-0103). Madrid: Ministerio de Educación: Secretaria general de política universitaria; $2011.470 \mathrm{p}$.

23. García Ayuso M, Larrinaga C. Environmental disclosure in Spain: Corporate characteristics and media exposure. Revista Española de Financiación y Contabilidad. 2003;2(115):184-214.

24. Larrinaga C, Llena F, Moneva JM, et al. Accountability and accounting regulation. The case of the Spanish environmental disclosure standard. European Accounting Review. 2002;11(4):723-740.

25. Cowen S, Ferrei L, Andparker L. The impact of corporate characteristics on social responsibility disclosure: a typology and frequency-based analysis. Accounting, organizations and society. 1987;12(2):111-122.

26. Gray R, Javad M, Power D, et al. Social and environmental disclosure and corporate characteristics: a research note and extension. Journal of Business Finance and Accounting. 2001;28(3-4):327-356.

27. Freeman RE. Strategic management: a stakeholder approach. Boston: Pitman; 1984. 276 p.

28. Mathews MR. Socially Responsible Accounting. UK: Chapman \& Hall; 1993. $250 \mathrm{p}$.

29. Suchman MC. Managing legitimacy: strategic and institutional approaches. Academy of Management Review. 1995;20(3):571-610.

30. Deegan C. The legitimacing effect of social and environmental disclosures. A theoretical foundation. Accounting, Auditing and Accountability Journal. 2002;15(3):281-311.

31. Roca L, Searcy C. An analysis of indicators disclosed in corporate sustainability reports. Journal of cleaner production. 2012;20(1):103118.

32. Nikolaeva R, Bicho M. The role of institutional and reputational factors in the voluntary adoption of corporate social responsibility reporting standards. Journal of the academy of marketing science .2011;39(1):136157.
33. Adams CA, Whelan G. Conceptualising future change in corporate sustainability reporting. Accounting, Auditing and Accountability Journal. 2009;22(1):118-143.

34. Artiach T, Lee D, Nelson D, et al. The determinants of corporate sustainability performance" Accounting and finance. 2010;50(1):31-51.

35. Hackston D, Y Milne M. Some determinants of social and environmental disclosures in New Zealand. Accounting, Auditing and Accountability Journal. 1996;9(1):77-108.

36. Llena F, Moneva JM, Hernández B. Environmental disclosures and compulsory accounting standards: the case of Spanish annual reports. Business Strategy and the Environment. 2007;16(1):50-63.

37. Fischer T, Sawczyn A. The relationship between corporate social performance and corporate financial performance and the role of innovation: evidence from German listed firms. Journal of Management Control. 2013;24(1):27-52.

38. Alvarez I, Ortas E, moneva jm. The interaction between CSP and CFP in Spanish companies; the impact of the global financial crisis. Pamplona: Communication at the XVII AECA Congress; 2013. p. 25-27.

39. Lamprinidi S, Kubo N. Debate: the global reporting initiative and public agencies. Public Money \& Management. 2008;28(2):326-329.

40. García Sánchez I, Frías Aceituno J, Rodríguez Dominguez L. Determinants of corporate social disclosure in Spanish local governments. Journal of cleaner production. 2013;39(3):60-72.

41. Farneti F, Guthrie J. Sustainability Reporting by Australian Public Sector Organisations: Why they Report. Accounting Forum. 2009;33(2):89-98.

42. Levy B, Marans R. Towards a campus culture of environmental sustainability: Recommendations for a large university. International journal of sustainability in higher education. 2012;13(4):365-377.

43. Ocde. Education at a glance. OECD indicators. USA: OCDE publishing; 2013. 440 p.

44. Coy D, Tower G, Dixon K. Quantifying the quality of tertiary education annual reports. Accounting and Finance.1993;33(2):121-130.

45. Marston C, Shrives P. The use of disclosure indices in accounting research: a review article. British Accounting Review.1991;23(3):195-210.

46. Cooke TE. Disclosure in the corporate reports of Swedish companies. Accounting and Business Research. 1989;19(74):113-124.

47. Buesa M, Heijs J, Kahwash O. Calidad de las universidades: elaboración de un índice sintético. UK: Ekonomiaz; 2009;70(1):206-239.

48. Buela casal G, Bermúdez M, Sierra J, et al. Ranking de 2010 en productividad en investigación de las universidades públicas españolas. Psicothema. 2011;23(4):527-536.

49. Banks W, Fisher J, Nelson M. University accountability in England, Wales and Northern Ireland: 1992-1994. Journal of International Accounting, Auditing \& Taxation. 1997;6 (2):211-226.

50. Murias P, De Miguel Jc, Rodriguez D. A composite indicator for university quality assessment: the case of the Spanish higher education system? Social indicator research. 2008;89(1):129-146.

51. Martín E. La rendición de cuentas de las universidades públicas españolas: un análisis de la información revelada en los estados financieros. Presupuesto y Gasto Público. 2006;43 (2):39-63.

52. Martín E. Rendición de cuentas en la educación superior: un análisis de las cuentas anuales de las universidades en España y el Reino Unido. Revista Contaduria Universidad de Antioquía. 2010;57(4):21-114.

53. Christiaens T, Wielemaker E. Financial accounting reform in Flemish 
universities: an empirical study of the implementation. Financial Accountability and Management. 2003;19(2):185-204.

54. Value of sustainability reporting. A study by Ernst \& Young LLP and Boston College Center for Corporate Citizenship. 2013. 32 p.

55. Lieberman M, Asaba S. Why do firms imitate each other. Journal of Management Review. 2006;31(2):366-385.

56. Guthrie J, Farneti F. GRI Sustainability Reporting by Australian Public Sector Organizations. Public Money \& Management. 2008; 28(6):361366.

57. Moneva JM, Archel P, Correa C. GRI and the camouflaging of corporate unsustainability. Accounting Forum. 2006;30(2):121-137.
58. Onu. Nuestro futuro común: Comisión de medioambiente y desarrollo de la Organización de Naciones Unidas. Oxford: Oxford University Press; 1987. $26 \mathrm{p}$.

59. Promoviendo un modelo de responsabilidad social en la Universidad de Zaragoza. Zaragoza: Universidades Responsables; 2007.91 p.

60. Ferrer Balas D, Adachi S, Davidson C, et al. An international comparative analysis of sustainability transformation across seven universities. International Journal of Sustainability in Higher Education. 2008;9(3):295-316 